efficacy of medicine or the skill of the physician. 'These things combined may nevertheless be of value in determining the intent of the mother. And it is the intent, the motive, which the law recognizes as of prime importance.

The case I wish to report is that of a child aged seven months. 'The mother was a woman of twentyfive who was working in a eheap hotel as helper in the kitchen. She elaimed to have been married five years. IIer husband, however, had left her three years before, though she claimed he hat been to visit her about a year and a half hefore the present time. The babe had been for six weeks at the Seaside llome, and though in a forlorn condition on its andmission, liad gained sufliciently to be thought ready to be discharged from the hospital. 'The mother was notilied, but firiled to call for it. During the six weeks of the ehild's stay at the home she hat never been to see it, though opportunities were frequent. Repeated requests hat no effect. 'Then the babe was taken by the overseers of the poor to the almshouse, where it remained two weeks. Our pauper methods, however, (lo not provide for maintaining a child in the poorhouse while its parent or parents remain outside. 'This mother, then, who was now supporting a child two years old, was told that she: must either declare herself destitute and join her younger babe in the almshouse, or she mpst support it herself outside. And being summoned before the oflicers at the police station she declared herself ahle and willing to provide for both children.

$\Lambda \mathrm{s}$ before stated, she was working at a cheap hotel, and this was within a stone's throw of the office of the overseess of the poor and the eity physician. Evidently fearing that the proprietor might object to the presence of two infants, she said nothing of the younger chili, but took it to her room, which was poorly lighted and ventilated. 'There for sixteen days the child was kept, never was taken from the room, no one was told of its existence. 'The mother manifested marked indifference as to the loss of the babe. She acknowledged that it had been sick for two weeks, but hiad not thought it neessary to send for a doctor. She knew the methorl of applying for the eity physician, and hat previously had him for the other clibld. She said that she had fed the younger child with milk when it would take fool. She had given it soothing syrup when it cried. In the room there was a bottle labelled "soothing syrup," and a man who worked in the hotel said thit he had been out for medicine (soothing syrup) several times. 'This he had supposed was for the two-year-old child. 'These facts were ascertained after noting the unusually filthy and neglected appearance of the body of the infunt, and as a result an antopsy was held September 14 th, forty-four hours after death.

The body was that of a male child twenty-five inches in length. It was extremely emaciated. Rigor mortis was present. The buttocks and genitals were red and inflamed. Vermin were present in the sores on the buttocks. The oral mucnous membrane was appiarently normal. Almost complete alosence of subcutaneous fat; skin dry and shrivelled; face pale and wrinkled. Heart and lungs were normal, thougl all the organs were markedly anemic. Stomach empty save for small amount of white, slimy deposit which was accepted as milk; bowels distended with gas, the walls thin and friable; the small intestine empty for its entiro length; no signs of any inflammatory condition; large intestine also empty, but deseconding colon and rectum showed slightly inflamed mucous membrane which was everywhere else very pale. Gall bladder was full. Kidneys, sploen, livere and pancereas appeareel normal. Brain was normal.

So far as could be ascertained from the autopsy, death had resulted from starvation, lut the slight indieations of colitis were suflicient to raise a possible doubt as to whether the starvation was due to disease or to the restraint of proper food. The mother was held by the district court on the charge of manslanghter, but she was not indieted by the gramd jury.

Reese says that although starvation " is rarely the cause of homicidal death, it should alway's be remembered that the law does not require the absolute deprivation of food to be proved, but only the neeessaly quantity and quality to be withhed, provided this has been done with an evil intent." It is important to know that the evidence of organic discase does not disprove that eriminal starvation may have been the cause of death. 'This because the defence set up is invariably that admitting the cause of death, it was the result of disense and not of maliee on the part of the one accused. 'Tidly quotes the statement of Ilippocrates that "The old bear want of nourishment best ; those who have attained the middle period of life the next in degree; those who have just arrived at puberty are less able to endure it; lut that of all ages, chililhood is the least capable of enduring hunger." It takes very little to kill an infant by refusing it the breast or giving it insuflicient or improper food.

The burelen of proof that the fatal result has been the outeome of wilful negleet on the part of the one having the care of a helpless child may at times not be liglit. 'The points particularly to be olserved in these cases are those usually indieative of starvation. In chronic cases the body is invariably shrunken and greatly emaciated. $\Lambda$ contracted state of stomach and bladder, a shrunken and transparent condition of intestines and omentum, with a more or less atroplicel, but otherwise healthy condition of the viscus, appear to be the prominent post-mortem symptoms. In acute starvation, however, one may find a consillerable layer of fat, as in the case of the Welsh fasting girl.

\section{Elinical \&Department.}

\section{THREE CASES OF GUNSHO'T WOUNDS.}

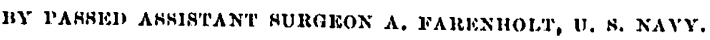

Case I. M. M. N., apprentice second class, I. S. Navy, age sixteen and one-half years, was shot through the head at Kabalition Islami, P. I., September 2 , 1899. The wound was made by a Spanish Mauser, calibre 8 millimetres, ball, and the distance from mu\%yle to head was but 2 feet. 1)ath occurred in about two hours after the receipt of injury, and the following conditions were observed at neeropsy : 'The posterior, or wound of entrance, was situated a little above the centre of right parietal bone, the anterior, 9 centimetres above nasion in median line of frontal bone; both wounds admitted little finger only to first joint. No staining of powder grains. Exopthalmos of left eye, pupils equal and moderately contracted. Sliglit movement of bones under scalp. 
Coronal suture patent ; fractures from posterior to anterior opening, and about 8 centinetres beyond each ; several small fractures from posterior wound in right parietal hone. C'alvarium removed ; brain sulstallece found disintegrated alosig path of bullet, and into surrounding tissues througli a diameter of 5 centimetres. Injury chiefly to right hemisphere except near anterior wound, where left was found injured; much blood elot and oozing from path of bullet. Surfaces of both hemispheres injected, base apparently molisturbed.

This case is interesting in showing that a modern, high-power bullet, passing through a bony cavity at very short range, may not cause a "ragged and enlarged opening" at the wound of exit, as we are so often reminded it does at somewhat greater ranges.

These two wounds were identical in size and character, admitting the little finger only to the first joint, and although fractures radiated from their bony parts, there was no movement in their immediate vicinity.

The so-called explosive effect was, however, apparent, the calvarium being extensively fractured and movable in places, and besides the complete disintegration of brain sulstance along the path of the bullet, that organ showed clearly by the marked injection and hemorrhage the severe pressure, hychrodynimic, to which it had been subjected.

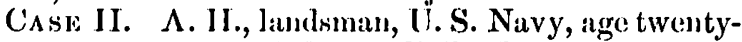
two years, was wounded near lloilo, P. I, (October 6, 18:99. He was probably shot by a 45-calibre Remington ball, the wound involving both thoracic and abdominal cavities. The patient lived, perfectly conscious, suffering only moderate pain, but paralyzed bolow the twelfth dorsal vertebra, for nine hours. The following conditions were found after death: Wound of entrance in axillary line at eighth rib, and that of exit 2 inches to right of median line of back and opposite the last dorsal vertebrat. (On section the abrlomen and pleural sac of left side wore found to contain considerable blood. Bullet in entering had gouged away a portion of eighth rib, left axillary line, and immediately perforated diaphragm without injury to lung; continuing, it lacerated the upper portion of spleen near its centre, and then entered the stomach at about the centre of the greater curvature. Emerging in the lesser curvature it lacerated extensively the head of the pancercas, impinged upon and glanced backward from the elevesth dorsal th vertebra, fractured its boly, transverse, articular and spinous processes with those of the anljoining verteblas, opened the spinal canal, lacerated the cord and emerged as noted. 'The wound of entrance in this case was round and clear cut, being $1 \frac{1}{2}$ centimetres in diameter, while that of exit was gouged out and ragred and fully 21 centimetres across.

CAsE III. In the same engagement $F . \Lambda$. apprentice, U. S. Navy, age eighteen years, was wounded by a Mauser ball, which passed directly through the hody just below the brim of the pelvis. When seen several hours later patient was in fair condition, very little slook. It was decirled, after consultation, not to operate, and the patient rallied well, notwithstanding the obvions fact that the rectum had been perforated, and continued to improve during the sulssequent ten days, exhibiting no signs of peritonitis or hemorrhage. Suddenly, on the night of the eleventh day, a severe hemorrhage from the posterior wound occurred, from which he reacted but partinlly under transfusion, only to succumb a few hours later to another uncontrollable hemorrhage. The following is the report of the necropsy: 'The wound of entrance was on the right sicle through the borly of the pubes, just external to the pubic spine; it was of a drilled nature and but slightly larerer than the 8-millimetre ball itself. 'The wound of exit was on the sames side, 3 centimetres internal from a point midway on a line from the posterior superior spine of the ilium to the tuber ischii, the ball pissing ont through the greater sacrosciatic foramen. The latter wound was $1 \frac{1}{2}$ centimetres in diameter and rather ragged. 'The rectum was perforated laterally with considerable loss of substance; the peritoneal cavity was not involved. $\Lambda$ cavity, corresponding to the path of the bullet, was filled with blood elots and feces and walled oft above hy thickened peritoneum which was adherent to the aldominal parietes. The bladder was displaced to the left and bound down by adhesions; the caput coli, ascending colon and sigmoid flexure were surrounded by adhesions, binding them to the abdominal walls and to adjacent structures. 'The cause of death was secondary hemorrhage from branches of the internal iliac artery. Wound was received at distance of about 70 yards.

\section{Mqedical Bragregg.}

\section{RECEN'T PROGRESS IN THERAPEUTICS.}

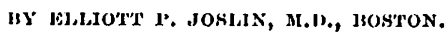

(Concluded from No. 19, p. 470.)

OXYBUTYRIC ACID AND J'TS REIATION TO DIABETIC COMA.

$\Lambda$ (avone and diacetic acid receive attention far beyond their due in the study of diabetes, and oxylutyric acid, though next to sugar in importance, is overlooked. The amount of acetone and diacetic acid seldom exceeds 10 grammes per day even in the severest cases of diabetes, while that of oxylutyric acid may reach 20 or 30 grammes, and in coma has risen to 160 grammes in the twenty-four hours. Oxybutyric acid has been neglected because its estimation is difficult. It is to be hoped that Dr. Magnus-Ievy, who has devoted so much of his time during the last three years to its study, will be able to offer a more simple and accurate method for its isolation than now exists. It is from his first publication of 90 parges on oxybutyric acid that the following partial résumé has been male.

The growth of our knowlenge regarding 13-oxybutyric acid has gone on in an exceptionally logical manner. In 1880 IIallervorden discovered a marked increase in the excretion of ammonia in diabotes. 'This amounted to six to eight times the quantity excreted by normal individuals on the same diet. Since the urine was always acid, he believed the increase in ammonia was chiefly due to an increase in the output of inorganic acids in the form of ammonia salts. Stadelmann investigated this, point in 188:3, and found it was the organic acids, not the inorganic, which were responsible for this excess. He was also able to show that the organic ach in question was one that yielded, on decomposition, crotonic acid. One year later Minkowski succeded in isolating the original acid in pure form, and claracterized it as 13-oxybutyric acid. Si- 